\title{
MENTAL DISORDER AFFECTING THE DEGREE OF A CRIME
}

\author{
HENRY WEIHOFEN† \\ WINFRED OVERHOLSER*
}

I

THAT a person who kills another without deliberation and premeditation cannot be held liable for first degree murder would seem selfevident under the usual statute defining the crime in terms of those mental elements; and this would seem to be true whether the lack of deliberation and premeditation was attributable to provoking circumstances, intoxication, mental disorder or any other cause.

It is somewhat surprising, therefore, that in the case of mental disorder, the cases are almost evenly divided on whether or not such disorder may be considered in determining whether a killing was committed with deliberation and premeditation. Fully half of the courts which have been confronted with the question have answered it in the negative, most of them disposing of the problem in a paragraph or two. They apply the doctrine that insanity is a defense only where the disorder is such as to come within the accepted "tests," and then it is a complete defense, requiring acquittal. This doctrine recognizes no middle ground between responsibility and irresponsibility, where mental disorder not sufficient to require acquittal may nevertheless serve to reduce the degree of the crime. In these states it would seem that a person can be held guilty of committing a premeditated killing even though he lacked the mental capacity to premeditate.

On the other hand, if the question is answered in the affirmative and courts recognize mental disorder, short of legal insanity, as a defense to the charge of first degree murder, the principle logically may extend to the point where lack of the intent required to constitute the crime supplants the accepted right-and-wrong test of criminal insanity.

Fisher v. United States ${ }^{1}$ presented this problem to the United States Supreme Court for the first time in 1946. Fisher was a Negro janitor in the library of the Cathedral of St. Peter and St. Paul in Washington, D. C. The librarian, Catherine Reardon, had complained to the verger about Fisher's care of the premises, and the verger had told Fisher about the complaint. On the morning of March 1, 1944, Miss Reardon and Fisher were alone in the library. According to his account, she scolded him and called him a "black nigger," whereupon he became

$\dagger$ Department of Justice; author of Insanity as a Defense ni Cramsiar Law.

* Superintendent, St. Elizabeths Hospital, Federal Security Agency, Washington, D.C.; Professor of Psychiatry, George Washington University School of Mfedieine

1. 328 U.S. 463 (1946), petition for rehearing denicd, 67 Sup. Ct. 24 (Oct. 14, 1946). See Taylor, Partial Insanity as Affecting the Degree of Crime-A Commentary on Fisher v. United States, 34 CALIF. L. REv. 625 (1946) ; Note, 46 CoL. L. RET. 1005 (1946). 
angry and struck her. She ran screaming toward a window and Fisher rushed out of the room. Her screams continued. Fisher saw a pile of wood, seized a piece, ran back, and struck her on the head. The stick broke and he seized her by the throat and choked her to silence. He then dragged her to a lavatory and left her there while he went back to clean up the spots of blood. She screamed again and Fisher returned to the lavatory and stuck her in the throat with his pocket knife (merely through the skin, the coroner said). She was silent then and he dragged the body down into an adjoining pump pit where it was found next day. He never wanted to kill Miss Reardon, he said, but only wanted to stop her screaming, which unnerved him.

The defense tried to show that the killing was not deliberate and premeditated, and was, therefore, only second degree murder. Although evidence of the accused's psychopathic tendencies, low emotional response and borderline mental deficiency was introduced, the trial court refused to instruct the jurors that they could consider these factors in determining whether Fisher was guilty of murder in the first or second degree. Acting under instructions defining accepted tests of insanity, malice, deliberation and premeditation, the jury found the defendant guilty of murder with deliberate and premeditated malice.

The Court of Appeals for the District of Columbia affirmed the conviction, and the Supreme Court granted certiorari. The only error urged by petitioner was the trial judge's refusal of an instruction which would have permitted the jury to weigh evidence of mental deficiencies -admittedly short of insanity in the sense of irresponsibility for crime under accepted tests-in determining the fact of, and the accused's capacity for, premeditation and deliberation.

In a 5-3 decision the Supreme Court upheld the trial judge's refusal to give the requested instruction. The majority, speaking through Justice Reed, discussed first the instructions actually given by the trial court and found them without error. The Court went on to say "The jury might not have reached the result it did if the theory of partial responsibility for his acts which the petitioner urges had been submitted." 2 But under the law of the District of Columbia, as established in United States v. Lee, ${ }^{3}$ the Court found that the accused was not entitled to an instruction on this theory, and it declined to force the District of Columbia to adopt a contrary rule. The majority stated that it expressed no "opinion upon whether the theory for which peti-

2. Id. at 470 . The term "partial responsibility" although it has been used by writers, including one of the authors of this article, is misleading. The theory does not contemplate that any offender should be held only "partially" responsible for his crimes. It contemplates full responsibility, but only for the crime actually committed. A better phrase would be mental disorder affecting the degree of crime, or mental disorder affecting the particular intent.

3. 4 Mackey 489 (Sup. Ct. D. C. 1886). 
tioner contends should or should not be made the law of the District of Columbia. Such a radical departure from common law concepts is more properly a subject for the exercise of legislative power or at least for the discretion of the courts of the District." "4

Justices Murphy, Frankfurter ${ }^{5}$ and Rutledge ${ }^{\circ}$ wrote dissenting opinions. The most important for the purposes of this article is that of Justice Murphy, because it is concurred in by the other two dissenters, and because it most directly discusses the question, which, as Justice Murphy phrases it, is: "May mental deficiency not amounting to complete insanity properly be considered by the jury in determining whether a homicide has been committed with the deliberation and premeditation necessary to constitute first degree murder?"

His answer is a vigorous affirmative. He points out that "between the two extremes of 'sanity' and 'insanity' lies every shade of disordered or deficient mental condition, grading imperceptibly into one another," and that there are persons who, while not totally insane, possess such low mental powers as to be incapable of the deliberation and premeditation requisite to statutory first degree murder. "Common sense and logic recoil" at a rule which requires the jury either to condemn such persons to death on the false premise that they are mentally capable of committing first degree murder, or to free them completely from criminal responsibility.?

On careful analysis the Fisher decision appears to be more of a victory than a defeat for the proposition that partial insanity may reduce the degree of a crime. It is true that the majority of the Court found no error in the trial judge's failure to give an instruction based on this theory. But the Court did not deny its soundness. The majority found it unnecessary to express any opinion on whether the theory should or should not be made the law of the District of Columbia. Three of the eight justices, on the other hand, believed it should. Thus, the first case in which the Supreme Court has considered the theory found three of the justices wholly favorable and five non-committal. For a doctrine

4. 328 U.S. 463,476 (1946).

5. Mr. Justice Frankfurter pointed out that Fisher's "whole behavior seems that of a man of primitive emotions reacting to the sudden stimulus of insult and proceeding from that point without purpose or design." Id. at 481. The dissent stated that in the particular circumstances of the case, it was the responsibility of the trial court to bring sharply and vividly to the jury's mind the crucial issue whether the requisite premeditation was in fact present or absent. Instead, "the instructions to the jury on the vital issue of premeditation consisted of threadbare generalities, a jumble of empty abstractions equally suitable for any other charge of murder with none of the elements that are distinctive about this case, mingled with talk about mental disease." Id. at 487.

6. MIr. Justice Rutledge concurred in the dissent by Mr. Justice Afurphy and in a separate opinion also agreed with Mr. Justice Franlfurter's view that the crucial issues of deliberation and premeditation were not adequately pointed up.

7. Id. at 494 . 
which has won approval from only half of the state courts to which it has been presented, this is a step forward.

II

The new prominence given by the Fisher case to the theory that mental disorder may affect the degree of a crime will almost certainly result in its being urged more often and more articulately than it has been hitherto. Indeed, it seems strange that the doctrine has not been asserted more often in the past, for this is no alien notion at war with common law concepts. It is merely an application in cases of mental disorder of the recognized general principle of our law that the state of mind with which a person commits a criminal act is important in determining not only whether he should be punished therefor, but also, if he is to be punished, how severely. Ordinarily, a person is not punished criminally unless he did the act with some wrongful state of mind. This fundamental principle of criminal justice is at least as old as Christian ethics. ${ }^{8}$ Some acts we punish only if done with specific intent to do that very act; others we punish even if done with an intent to do something nearly as bad; still others we punish even if there was no intent to do anything wrongful at all, but merely a high degree of carelessness. We also have a growing body of statutory crimes in which intent is wholly irrelevant, but these still constitute merely a minor exception to the rule that we do not punish criminally unless there is a concurrence of act and intent. The word "intent," although commonly used in this connection, is not a very apt term to describe the mental element requisite for each crime, covering as it does not only the specific intent necessary in some crimes, and the general intent to do wrong which is sufficient in other crimes, but also criminal negligence, which should not properly be called "intent" at all.

If the mental state requisite to a given crime is absent, the crime has not been committed. To what cause the absence of such mental state is to be attributed would seem immaterial. Intoxication furnishes the best example. Intoxication is not a circumstance that excites any sympathy. Unless involuntary, it is no defense to criminal liability. Nevertheless, if it is proved that a defendant charged with a deliberate and premeditated killing was too drunk at the time to deliberate and premeditate, he cannot be convicted of first degree murder; he must be convicted, if at all, of some lesser degree of homicide, not because we countenance drunkenness as a mitigating circumstance, but because he did not commit the

8. Hali, Principles of Criminal Law 143-7 (1947); 2 Holdsworta, History of English Law 53 (1895); 2 Pollock and Maitland, History of English LaW 474-5 (1895); Sayre, The Present Signification of Mens Rea in the Criminal Law, HARvard Legal Essays 399, 401 (1934); Crotty, The History of Insanity as a Deferse to Crime in English Criminal Law, 12 CALIF. L. REv. 105, 110 (1924). 
more serious crime. ${ }^{9}$ If we are willing to recognize this reasoning in the instance of intoxication, why not apply the principle in any situation where for any reason the defendant is in fact incapable of forming or entertaining the state of mind requisite to the crime charged? The Supreme Court itself stated the rule in an early intoxication case, Hopt $v$. People: ${ }^{10}$

"But when a statute establishing different degrees of murder requires deliberate premeditation in order to constitute murder in the first degree, the question whether the accused is in such condition of mind, by reason of drunkenness or otherdise, as to be capable of deliberate premeditation, necessarily becomes a material subject of consideration by the jury." (Italics added.) 11

A number of state courts have similarly used language broad enough to include insanity as well as intoxication. ${ }^{12}$

In insanity cases mechanical application of the accepted "tests" often obscures the essential principle upon which they are based: that a person should not be punished for a crime if, for any reason, he did not entertain the state of mind requisite to constitute the crime. Yet when jurists take time to state their major premises, this fundamental rationale inevitably presents itself. In the early leading case of Commonwealth v. Rogers, ${ }^{13}$ Chief Justice Shaw began his charge to the jury with the observation, "In order to constitute a crime, a person must

9. "Intoxication is admissible in such cases, not as an excuse for crime, not in mitigation of punishment, but as tending to show that the less and not the greater oficnse was in fact committed." State v. Johnson, 40 Conn. 136 (1873). Accord: Pirtle v. State, 28 Tenn. 663, 670 (1849).

10. 104 U.S. 631, 634 (1881).

11. In the Fisher case, Mr. Justice Reed, after referring to the Hopt case, says: "It should be noted, however, that the Territory of Utah had a statute specifically" establishing such a rule." This was true, but the statement quoted above was not made with reference to that statute; rather it was based expressly on the statute dividing murder into degrees and requiring deliberate premeditation to constitute murder in the first degree - a form of statute in effect in the District of Columbia no less than in Utah.

12. People v. Belencia, 21 Cal. 544, 545 (1863) ; People v. Brislane, 295 Ill. 241, 247, 129 N.E. 185, 187 (1920) ("whether from intoxication or any other causes") ; People v. Walker, 38 Mich. 156, 158 (1878) (if "for any reason whatever" accused did not indulge the criminal intent, crime was not committed); State v. Garvey, 11 Alinn. 154, 163 (1866) (insanity of any kind or from any cause rendering accused incapable of forming intent, is admissible to prove him innocent of that crime); Wilson v. State, 60 N.J.L. 171, 37 Atl. 428 (1897) ("drunkenness or any other cause") ; Pigman v. State, 14 Ohio 555, 556 (1846) ("any state or condition of the person that is adverse to the proper exercise of the mind") ; Commonwealth v. Hillman, $189 \mathrm{~Pa} .548,42$ Atl. 195 (1899); Pirtle v. State, 23 Tenn. 663, 670 (1849) ("drunkenness or other cause"). See also Johnson v. State, 24 So.2d 228, 230 (Ala. 1945), where it was said: "It is not the province or purpose of the law to hold a totally irresponsible person, a person of disordered and deranged mind (without reference to the cause of such condition), accountable for his acts."

13. 48 Mass. 500, 501 (1884). 
have intelligence and capacity enough to have a criminal intent and purpose," However, as Professor Keedy pointed out in analyzing this famous charge, ${ }^{14}$ Chief Justice Shaw promptly moved to a somewhat confused discussion of mental phenomena instead of following his statement with a discussion of the concept of criminal intent.

In 1869 , in Stevens v. State, ${ }^{15}$ the Indiana court said, "In a criminal case the jury must be satisfied beyond a reasonable doubt of the defendant's mental capacity to commit the crime charged. This is but an application of the general principle that the criminal intent must be proved, as well as the act; that without a capable mind such intent cannot exist, the very element of crime being lacking." Similar statements can be found in other cases. ${ }^{16}$ In New Hampshire and apparently also in Montana, this principle has been held to constitute the entire law or the subject, all "tests" for its application being rejected as matter for scientific proof, and not for legal rules. ${ }^{17}$

If insanity is a defense because it negatives the state of mind requisite to the crime charged, there is no logical escape from the proposition that if the defendant, because of mental disorders short of insanity, was incapable of premeditating and deliberating the killing and in fact did not deliberate or premeditate, he cannot be guilty of a crime which by definition requires these mental elements. If, however, he was able to understand the nature of the act he was committing and if he intended to do that act, understanding that it would certainly or probably cause death, he should be found guilty of murder in the second degree or manslaughter. There is no logic in the "all or nothing" assumption underlying our usual thinking on the effect of mental disorder on criminal responsibility-the assumption that a person is either "sane" and consequently fully responsible for all his acts, or else "insane" and wholly irresponsible.

The reason why defense counsel have not urged the proposition more often can only be surmised. The most probable reason would seem to be that they have been distracted by the "tests" of insanity, which purport to be comprehensive and to cover the subject. Counsel are

14. Keedy, Insanity and Criminal Responsibility, 30 HARv. L. REv. 535 and 724, 727 (1917).

15. 31 Ind. 485,491 (1869).

16. State v. Brown, 36 Utah 46, 102 Pac. 641 (1909) ("Since a criminal intent is an essential element of crime, if by reason of insanity a person is incapable of forming any intent, he cannot be regarded as guilty by law.") See Hotema v. United States, 186 U.S. 413, 417-9 (1902) ; United States v. Fore, 38 F. Supp. 140, 141 (S. D. Cal. 1941) ; 1 Brs rop, Criminal law $\$ 381$ (2) (9th ed. 1923); 2 Stephen, History of tre Criminal Law op ENGLAND 97 (1883); 15 Harv. L. REv. 499 (1902).

17. State v. Pike, 49 N.H. 399 (1869) ; State v. Jones, 50 N.H. 369 (1871); State v. Peel, 23 Mont. 358, 59 Pac. 169 (1899) ; State v. Keerl, 29 Mont. 508, 75 Pac. 362 (1904); State v. Crowe, 39 Mont. 174, 102 Pac. 579 (1909); State v. Marich, 92 Mont. 17, 9 P.2d 477 (1932). 
therefore led to try to prove that their clients come within the test, and to assume that unless they can so prove, mental abnormality is irrelevant.

\section{III}

Justice Reed, in the majority opinion in the Fisher case lists sixteen cases as having adopted the rule and twenty-four as having rejected it. Careful reading of these cases reveals that some are distinguishable in that they do not actually involve or even discuss this issue, and others discuss it merely in dicta. Grouping the cases (those cited by the Supreme Court plus a few not cited) by states, the writers would classify them as follows:

Arizona, ${ }^{18}$ Idaho ${ }^{19}$ and Missouri ${ }^{20}$ have rejected the rule and so, perhaps, have California, ${ }^{21}$ the District of Columbia, ${ }^{22}$ Massachusetts, ${ }^{23}$ Nevada, ${ }^{24}$ New Jersey ${ }^{25}$ and Pennsylvania, ${ }^{20}$ although it is possible to

18. Foster v. State, 37 Ariz. 281, 289-90, 294 Pac. 268, 270-1 (1930).

19. State v. Van Vlack, 57 Idaho 316, 360-7, 65 P.2d 736, 750-1 (1937).

20. State v. Halloway, 156 Mo. 222, 231, 56 S.W. 734, 736 (1900).

21. People v. Troche, $206 \mathrm{Cal}$. 35, 46, $273 \mathrm{Pac} .767,772$ (1923) (strictly, only question involved was whether, under statute providing for separate trials on insanity and other issues, court was correct in excluding all evidence of mental condition on irial of the main issue; held, yes); People v. French, 12 Cal. 2d 720, 738, 87 P.2d 1014, 1023 (1939) (does not involve rule in question, but only contention that defendant's mental condition might be considered by the jury in determining what punishment to assess if defendant was found guilty of murder in the first degree, under California statute giving the jury discretion to fix punishment at death or life imprisonment) ; People v. Cordova, 14 Cal.2d 30S, 311-2, 94 P.2d 40, 42 (1939) (involves solely an attack upon constitutionality of California statutes providing for separate trial of sanity from other issues). Cf. People $\nabla$. Belencia, $21 \mathrm{Cal}$. 544, 545 (1863) (in determining degree of murder, "any evidence tending to show the mental status of the defendant" held admissible).

22. United States v. Lee, 4 Mackey 489 (Sup. Ct. D. C. 18\$6).

23. Commonwealth v. Cooper, 219 Mass. 1, 5, 105 N.E. 545, 547 (1914) (instruction based on the theory, "except as covered by the instructions," held properly denied; instructions given told jury that "defendant could not be convicted if from mental disease he was unable to form a criminal intent or purpose, and acted under an irresistible impulse"). Cf. Commonwealth v. Clark, 292 Mass. 409, 198 N.E. 641 (1935).

24. State v. Skaug, 161 P.2d 708 (Nev. 1945). In this case, an instruction perhaps based on the theory but poorly worded and not supported by citation of authorities, was held properly refused.

25. State v. Rodia, 132 N.J.L. 199, 39 A.2d 484 (1944) (trial court had commented adversely on testimony of experts as to defendant's mental age introduced to show that he was incapable of planning, premeditating or designing with intent to kill Held, 9-7, judge's right to comment was clear. Minority deemed the comment prejudicial error; the testimony had been properly admitted, for the degree of mental capscity may "be a determining factor on the issue of the existence of a deliberate and premeditated design to kill") ; State v. Noel, 102 N.J.L. 659, 676-7, 133 Atl. 274, 279-S0 (1926) (conviction reversed because court feit defendant did not know nature of the act or difference between right and wrong; no clear discussion in majority opinion of the rule regarding reduction in degree; minority, concurring, specifically favors the rule); State v. James, 96 N.J.L. $132,149-51,114$ At1. 553, 560-1 (1921) (involved use of evidence of mental condition as 
distinguish most of the cases from these jurisdictions. Arkansas, ${ }^{27}$ Texas ${ }^{28}$ and Washington, ${ }^{29}$ although represented among the cases

a basis for jury recommendation of life imprisonment statute; rule regarding reduction in degree of crime not involved) ; State v. Maioni, 78 N.J.L. 339, 74 Atl. 526 (1909) (instruction that insanity cannot reduce crime from first degree to second degree murder upheld). Cf. Wilson v. State, 60 N.J.L. 171, 37 Atl. 428 (1897) (if, "by reason of drunkenness or any other cause," prisoner is incapable of deliberation and premeditation, the crime has not been committed) ; State v. Close, 106 N.J.L. 321, 148 Atl. 764 (1930) scmblc.

26. Commonwealth v. Hollinger, 190 Pa. 155, 160, 42 Atl. 548, 550-1 (1899); Commonwealth v. Scott, 14 Pa. D. \& C. 191, 196-8 (1930). See Jacobs v. Commonwealth, 121 $\mathrm{Pa} .586,592-3$ (1888) (questions regarding defendant's temperament, disposition, excitability, and whether these influenced his mind so that he was incapable of deliberating and premeditating held properly excluded; "the evil dispositions of a defendant were not admissible in evidence for the purpose of excusing or mitigating his crime") ; Commonwealth v. Wireback, $190^{\circ} \mathrm{Pa} .138,151-2,42$ Atl. 542, 546-7 (1899) (question of insanity reducing degree of crime not involved; the following dictum is pertinent: "To say that a man is insane to an extent which incapacitates him from fully forming an intent to take life, yet enables him to fully and maliciously form an intent to do great bodily harm without a purpose to take life, is absurd, for the one involves the same test of responsibility as the other, the ability to distinguish between right and wrong"); Commonwealth $v$. Heidler, $191 \mathrm{~Pa} .375,43$ Atl. 211 (1899) (also involves only burden of proof; court quotes Wireback case; a dictum on a dictum); Commonwealth v. Barner, $199 \mathrm{~Pa} .335,342,49$ Atl. 60, 64 (1901) (semble); Commonwealth v. Szachewicz, 303 Pa. 410, 416-7, 154 Atl. 483 (1931) (dictum).

The proposition denied as absurd in the Wireback case has little resemblance to the theory involved in the rule that mental disorder may affect the degree of crime. In the court's example, the mental state requisite to the two crimes is essentially the same-intent to take life and intent to do great bodily harm. There is greater difference between the mental state of deliberately and premeditatively taking life and doing so with "malice aforethought" but without deliberation and premeditation.

In a number of cases, the Pennsylvania court has expressly or tacitly approved instructions that if the self-governing power was wanting, by reason of intoxication or insanity, the accused cannot be said to have deliberated or premeditated in the sense required for first degree murder. Nevling v. Commonwealth, $98 \mathrm{~Pa} .322$ (1881); Commonwealth v. Werling, $164 \mathrm{~Pa} .559,30$ Atl. 406 (1894); Commonwealth v. Fillman, $189 \mathrm{~Pa} .548,42$ Atl. 196 (1899); and see Commonwealth v. Sherer, 266 Pa. 210, 109 Atl. 867 (1920); Jones v. Commonwealth, $75 \mathrm{~Pa} .403$ (1874).

27. In Bell v. State, 120 Ark. 530, 558, 180 S.W. 186, 197 (1915), an instruction for the state, objected to by defendant, was held misleading "and highly prejudlicial to the defendant." The case does not deny that a defendant might be entitled to such an instruction properly worded.

28. Hogue v. State, 65 Tex. Cr. 539, 542, 146 S.W. 905, 907 (1912) contained a dictum that: "This court has never recognized the doctrine that a person with a mind below normal should be punished for a lower grade of offense if found guilty than a person of normal mind. . . Evidence may be introduced for the purpose of showing defendant's state of mind, as establishing his intent and fixing the grade of the offense, but if a person has sufficient intelligence to know right from wrong he is legally responsible for his acts." This seems to accept rather than reject the rule that mental unsoundness may be shown to negative criminal intent. Witty v. State, 75 Tex. Cr. 440, 171 S.W. 229 (1914) merely held that delusions of threats against defendant and his family, which had excited his mind, would not prevent conviction of murder; and is not in point.

29. State v. Schneider, 158 Wash. 504, 291 Pac. 1093 (1930) involved only a question 
cited as opposing the rule, cannot properly be included, for the cases from these states are clearly distinguishable.

Connecticut, ${ }^{30}$ Illinois, ${ }^{31}$ Utah, $^{32}$ Virginia, ${ }^{33}$ and $\mathrm{WT}{ }^{\mathrm{isconsin}}{ }^{34}$ have more or less clearly adopted the rule, and perhaps Indiana ${ }^{35}$ and Kentucky ${ }^{36}$ too. Maryland ${ }^{37}$ and New York ${ }^{38}$ in dicta have also approved the rule. In addition, the courts of Alabama, Michigan, Minnesota,

of pleading: "whether defendant could raise defense of reduction of crithe under a special plea of insanity and mental irresponsibility." The court did not discuss the merits of the defense.

30. Anderson v. State, 43 Conn. 514, 526 (1876) ; State v. Johnson, 40 Conn. 136, $143-4$ (1873) ; State v. Saxon, 87 Conn. 5, 86 At1. 590 (1913).

31. Fisher v. People, 23 III. 283 (1860); and see People v. Brislane, 295 IIl. 241, 247, 129 N.E. 185, 198 (1920) (if accused, at time of act, "was wholly incapable of forming the intent charged, whether from intoxication or any other cause, he is guilty of no crime").

32. State v. Anselmo, 46 Utah 137, 148 Pac. 1071 (1915); State v. Green, 78 Utah 580, 6 P.2d 177 (1931).

33. Dejarnette v. Commonwealth, 75 Va. 867 (18S1).

34. Hempton v. State, 111 Wis. 127, S6 N.W. 596 (1901); Oborn v. State, 143 Wis. 249, 126 N.W. 737 (1910).

35. Aszman v. State, 123 Ind. 347, 356, 24 N.E. 123, 126 (1889); Donahue v. State, 165 Ind. 148, 156, 74 N.E. 996, 999 (1905). In Sage v. State, 91 Ind. 141 (18s3), the court properly rejected a requested instruction to the effect that if defendant was "partially" insane, he might be found guilty in a less degree than charged. But the court also added that "independently of any question of insanity the defendant in a criminal cause has the right to have his general physical as well as his mental condition at the time of the commission of the supposed crime explained to the jury, so as to put them in possession of all the facts connected with the transaction, and the better to enable them to judge of its character." In Robinson v. State, 113 Ind. 510, 513, 16 NN.E. 184, 186 (1887), it was said that while weakmindedness is no defense, it is "to be considered as bearing upon the intent with which he took the property."

36. Rogers v. Commonwealth, 96 Ky. 24, 27 S.IW. 813 (1S94); Mangrum v. State, 19 Ky. Law Rep. 94 (1897). But sec Perciful v. Commonwealth, 212 Ky. 673, 678, 279 S.W. 1062, 1064 (1925) (defendant convicted of murder alleged error in refusing a manslaughter instruction; held, there was no evidence of "heat of passion" or other factors showing manslaughter, and "as insanity excuses altogether ... proof of insanity other than drunlienness would not authorize a manslaughter instruction").

37. Spencer v. State, 69 Mrd. 28, 41-3 (18s8). The trial court reiused to admit evidence that defendant had been restless and nervous, etc, his counsel having refused to give assurance that this would be followed up by other proof tending to show insanity at time of the homicide, and no specific object having been avowed for offering the evidence. In the Supreme Court, it was argued that one ground of admissibility was that the evidence affected the degree of the crime. The court conceded the principle relied upon, but held that here, all the evidence, including defendant's, showed the most deliberate premeditation and that the evidence was correctly excluded.

38. See People v. Moran, 249 N.Y. 179, 180, 163 N.E. 553 (1928). But ef. Sindram v. People, 88 N.Y. 196, 200-201 (18S2) (no "insanity" involved, but only contention that court should have admitted certain lay testimony of defendant's peculiarities and passionate character; held: ". . . the theory that eccentricities of character or inordinate passion can render a sane man incapable of committing an offense which involves deliberation is wholly inadmissible"). 
Ohio and Tennessee, as well as the United States Supreme Court ${ }^{39}$ have in intoxication cases employed broad language to the effect that if the accused, because of drunkenness or otherwise, did not have the requisite state of mind, he cannot be held guilty of the crime charged. Most of the courts which reject the theory adopt the "all or nothing" reasoning referred to above. ${ }^{40}$ United States $v$. Lee, cited by the Supreme Court in the Fisher case as having established the law for the District of Columbia, is typical. The trial court in that case had refused to instruct the jury that if they found such mental unsoundness as to render the defendant incapable of premeditation and of forming such an intent as would be imputed to a sane man, they could weigh such unsoundness in determining whether the act was murder or manslaughter. The District of Columbia law at that time did not divide the crime of murder into degrees, and the prosecuting attorney in the Lee case emphasized this fact in his argument.

"In jurisdictions where murder is divided into two degreesmurder in the first degree requiring deliberation and premeditation; in other words, actual malice-it has been frequently held that evidence of mental excitement resulting from drunkenness and, perhaps, also of other abnormal conditions of the mind not amounting to insanity, may reduce an unprovoked homicide to murder in the second degree; but it has always been held that such evidence cannot of itself reduce the crime to manslaughter." 41

The Supreme Court of the District affirmed the conviction and held that the requested instruction was correctly refused, stating two grounds. The first was that "there was no evidence whatsoever upon which to found the prayer." The only evidence offered by the defense on the subject of insanity was that of lay witnesses who testified that on the day of the killing the defendant acted "like he was crazy," that he had been drinking frequently for several weeks, and that after the shooting he appeared as though he had been drinking. No one testified to an opinion that he was insane. On the evidentiary ground alone, therefore, the court was certainly justified in holding that the instruction was properly refused.

But the court voiced a second criticism: that the requested instruction was "incongruous and radically vicious," because "It rests upon the idea that there is a grade of insanity not sufficient to acquit the

39. See notes 10 and 12 supra.

40. Foster v. State, 37 Ariz. 281, 289-90, 294 Pac. 268, 271 (1930) ; People v. Troche, 206 Cal. 35, 46, 273 Pac. 767, 772 (1928); United States v. Lee, 4 Mackey 489 (Sup. Ct. D.C. 1886); Commonwealth v. Cooper, 219 Mass. 1, 5, 106 N.E. 545, 547 (1914) ; State v. Holloway, 156 Mo. 222, 231, 56 S.W. 734, 736 (1900) ; State v. Maioni, 78 N.J.L. 339, 74 At1. 526 (1909).

41. United States v. Lee, 4 Mackey 489, 493 (Sup. Ct. D.C. 1886). 
party of the crime of manslaughter and yet sufficient to acquit him of the crime of murder." The law, said the court, does not recognize any such distinction; the test is knowledge of right and wrong, and if the accused could distinguish between right and wrong so as to be guilty of manslaughter he surely could do so with respect to murder.

The Lee case can be distinguished on two grounds: (1) the first reason stated by the District Supreme Court being sufficient, the second was merely surplusage; (2) the contention that mental abnormality may reduce a killing from murder to manslaughter is different from the contention that it may reduce it from murder in the first degree to murder in the second degree; the Lee case had involved only the former contention, while the Fisher case involved the latter.

The Supreme Court in the Fisher case specifically rejected this second suggested distinction. "As capacity of a defendant to have malice," said Mr. Justice Reed, "would depend upon the same kind of evidence and instruction which is urged here, it cannot properly be said that the separation of murder into degrees introduced a new situation into the law of the District of Columbia." 42

This can only be regarded as an unconsidered statement which the Court would hardly undertake to uphold on fuller analysis. A defendant's capacity for malice aforethought does not depend upon the same evidence as does his capacity for deliberation and premeditation. The murder-manslaughter distinction has a wholly different history and is based on wholly different criteria from those involved in distinguishing degrees of murder. The former is of common law origin, the latter statutory; the former involves an objective test, the latter subjective. ${ }^{43}$ The provocation which at common law reduces a homicide to manslaughter must be such as is calculated to produce hot blood or passion in a reasonable man, an average man of ordinary self-control. 44 Unless

42. 328 U.S. $463,473$.

43. On the historical development of "malice aforethought" into a concept wholly governed by external, objective criteria, see Communication to the Legislature, N.Y. Law Revision Commission, Leg. Doc. (1937) No. 65, pp. 536-40, quoted in HALL and GluzcE, Cases on Cratrinal Law 83 (1940).

44. This is all that is held by most of the cases cited by Mrr. Justice Reed. Hart $v$. United States, 130 F.2d 456 (App. D.C. 1942); Bishop v. United States, 107 F.2d 297 (App. D.C. 1939); McHargue v. Commonwealth, 231 Ky. 82, 21 S.W.2d 115 (1929). The

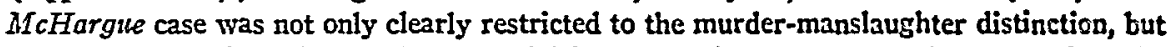
was decided in a jurisdiction where the division of murder into degrees does not exist. The Bishop case goes further, and holds directly contra to Mfr. Justice Reed's statement quoted above. The court said that capacity to have malice does not depend upon the same lind of evidence and instruction required in distinguishing first and second degree murder. Intoxication "may negative the ability of the defendant to form the specific intent to bill, or the deliberation or premeditation necessary to constitute first degree murder, in which event there is a reduction to second degree murder," but "as between the two offenses of murder in the second degree, and manslaughter, the drunkenness of the offender can form no legitimate matter of inquiry," for to constitute manslaughter, "it is only necessary to 
it meets this objective standard of reasonableness, the subjective fact of passion does not make the killing manslaughter. Such factors as mental abnormality or intoxication are therefore irrelevant, since the "reasonable man" standard postulates a sane and sober man. ${ }^{45}$ But the statutes dividing murder into degrees require by definition that for first degree murder the prosecution prove the actual existence of premeditation and deliberation. ${ }^{46}$ In determining the existence of these mental elements, abnormality, peculiarity, aberration, drunkenness, fatigue or any other condition tending to disprove their existence is admissible in evidence and should be taken into consideration. ${ }^{47}$

The distinction between these two doctrines has been maintained by the District of Columbia courts themselves. Subsequent to the Lee case, the crime of murder was divided into degrees by statute, and under that statute it has been held that evidence of intoxication rendering the accused incapable of deliberate premeditation requires an instruction that, if so incapacitated, he cannot be convicted of first degree murder. ${ }^{48}$ Prior to the adoption of the statute, intoxication was no defense to common law murder. ${ }^{49}$

Justices Frankfurter and Rutledge in the Fisher case both called attention to the fact that the Lee case involved only the murdermanslaughter distinction and not the then non-existent distinction

show that the killing was committed in 'heat of passion' upon sufficient provocation. The test of sufficiency of such provocation is that which would cause an ordinary man, a reasonable man, or an average man, to become so aroused." Bishop v. United States, supra, at $135-6$.

Of the four cases cited by Mr. Justice Reed, only one supports his statement, State v. Eaton, 154 S.W.2d 767 (Mo. 1941)-in the sense that the Missouri court there also failed to observe the distinction between the two doctrines. Other courts have at times been guilty of the same confusion. See, e.g., State v. Gounagias, 88 Wash. 304, 153 Pac. 9 (1915), holding that evidence of provocation insufficient to reduce homicide to manslaughter was ipso facto insufficient to reduce it from first to second degree murder; and State v. Holmes, 12 Wash. 169, 40 Pac. 735 (1895).

45. Rex v. Lesbini [1914] 3 K.B. 1116; People v. Hurtado, 63 Cal. 288 (1883), aff'd, 110 U.S. 516; Upstone v. People, 109 I11. 169 (1883) ; Gustavenson v. State, 10 Wyo. 300, 68 Pac. 1006 (1902).

46. Unless the prosecution proves deliberation and premeditation, the inference is that a killing with malice aforethought is murder in the second degree. State v. Friedrich, 4 Wash. 204, $29 \mathrm{Pac} .1055$ (1892). The "felony murders" also included in first degrce murder are not involved in the problem discussed in this article and for present purposes can be disregarded.

47. A leading case applying the correct rule is People v. Caruso, 246 N.Y. 437, 159 N.E. 390 (1927). See also cases cited note 58 infra; Wharton, Crrunna Law $\$ 516$ (12th ed.) The point discussed in this paragraph was called to the writers' attention by Professor Sheldon Glueck of the Harvard Law School who has kindly read a draft of this article.

48. McAffee v. United States, 111 F.2d 199, 205 n.15 App. D.C. 1940.

49. Bishop v. United States, 107 F.2d 297, 301 (App. D.C. 1939). 
between murder in the first and murder in the second degree. ${ }^{20}$ The majority cited no case in which the District courts had held that the effect of the new code provision was restricted to intoxication cases. Thus, the case which the majority relied upon as establishing a rule of local law "long established and deeply rooted" was based upon a statute now superseded by a statute of a type which the prosecution in that case conceded would have justified a different result. The statutory revision admittedly changed the prior rule so far as intoxication is concerned and its effect as to the logically similar defense of partial insanity had not previously been passed upon by the local courts.

But accepting the Lee case as establishing a rule, its reasoning is the "no middle ground" argument stated above, found also in half a dozen cases from other jurisdictions. The fallacy in this reasoning lies in allowing the "test" of insanity to overshadow the fundamental principle of which the test is merely a rule-of-thumb application. The principle, as already stated, is that a person who is mentally incapable of entertaining the wrongful state of mind required to constitute a crime should not be held guilty of that crime. As specific tests for the application of this principle became crystallized, judges tended to apply the tests mechanically, without regard to their rationale. It is a common phenomenon. Infancy and compulsion, like insanity, are also defenses resting on the premise that they negative criminal intent or wrongful state of mind, even though each has its own little body of rules or "tests." In the defense of mistake of fact, too, as Austin has pointed out, although the proximate ground is ignorance or error, the ultimate ground is the absence of unlawful intention or unlawful inadvertence. ${ }^{51}$ In the administration of all these defenses, concentrating attention on the "tests," the rules of thumb, causes us to lose sight of the basic proposition on which the rules are premised.52

50. 328 U.S. 463,489 n.11. Justice Rutledge stated that he did not think that Congress, by introducing the requirements of premeditation and deliberation into the District Code, intended to change the preexisting law only in cases of intosication.

51. Austin, Jurisprudence $\$ 687$ (Campbell ed. 1875). See also Keedy, Ignoruree and Mistake in the Crininal Law, 22 HARv. L. REv. 75 (1908).

52. This tendency has been peculiarly fostered in insanity cases by the impressive authority of the opinion in A'Naghten's Case, 10 Clark and Fin. 200 (1843) in which all the judges of England, upon Parliamentary request, undertook in an advisory opinion to formulate the specific terms in which the question should be left to the jury. Prior to this opinion, although ability to distinguish right from wrong had been pointed to as a criterion in determining sanity, it had been in the course of general discussion, more as an example or illustration than as a rule or exclusive test. Where linowledge of right and wrong was not felt to be the appropriate test, other criteria were used, as in Hadfield's Case, 27 How: St. Tr. 1281 (K.B. 1800).

There Hadfield, who had been wounded in the head and discharged from the army on the ground of insanity, was charged with shooting at King George III. His counsel, Lord Erskine, told the jury that Hadfield suffered from delusions that, like Jesus Christ, he was to sacrifice himself for the world's salvation; because he would not commit suicide, which 
Granting for present purposes the validity of the accepted tests for their intended purpose - namely, that of providing a specific criterion by which the jury may determine whether a defendant is so disordered as to be wholly irresponsible for crime-pointing to such tests is no answer to the basic question: how can one justify holding a person guilty of a deliberate and premeditated killing when he did not deliberate and premeditate, and, indeed, was incapable of deliberating and premeditating?

\section{IV}

Only two cases, strangely enough, refer to practical difficulties as reasons for not considering mental disorder as affecting the degree of a crime. In Commonwealth v. Hollinger, ${ }^{53}$ the Pennsylvania court stated the problem as follows:

"The courts do not ask the jury to undertake the impossible task of discriminating between degrees of insanity so as to find a prisoner incapable of forming a deliberate and premeditated intent to kill, while he has still so much sanity that he is a person of sound memory and discretion, as he must be to be guilty of murder even in the second degree."

The other case adopting this reasoning, State $v$. Van Vlack, ${ }^{54}$ is almost the only decision rejecting the theory in which there is a careful examination of its merits. There, the Idaho court argued as follows: the theory assumes that the accepted right and wrong test is an adequate test for malice aforethought, since that is the test universally applied; if a person under the accepted test possesses ability to entertain malice aforethought, the theory contended for must be based upon two propositions, first, that one must possess greater mentality to deliberate and premeditate than to possess malice aforethought, and second, there must be some standard for determining whether the individual possesses such added mental ability. "It is therefore," the court said, "not

he deemed wrong, he shot at the King so that "by the appearance of crime his life might be taken away from him by others." Id. at 1321. The defense was stopped and the jury returned a verdict of not guilty by reason of insanity.

Stephen has pointed out how the right-and-wrong test was slighted in that case. "In this case Hadfield clearly knew the nature of his act, namely, that he was firing a loaded horse pistol at George III. He also knew the quality of his act, namely, that it was what the law calls high treason. He also knew that it was wrong (in the sense of being forbidden by law), for the very object for which he did it was that he might be put to death so that the world might be saved; and his reluctance to commit suicide shows he had some moral sentiments." 2 StzpheN, History of the CrinINALL LAw 159 (1883).

53. $190 \mathrm{~Pa} .155,160$ (1899).

54. 57 Idaho 316, 65 P.2d 736 (1937). A Pennsylvania lower court decision also contains a carefully considered discussion of the question. Commonwealth v. Scott, $14 \mathrm{~Pa}$. D. \& C. 191 (1930). 
a question of partial insanity but of mental ability." ss This comment alone shows a clearer comprehension of the argument than is shown by older cases which dispose of the matter by refusing to recognize any "middle ground" of "partial insanity."

The Idaho court's first argument against the instruction requested in the Van Vlack case was that it "would have compelled the jury to find the defendant guilty of murder in the second degree even though he had not sufficient mentality to have malice aforethought." This suggestion must have come as a surprise to defendant's counsel, who surely had no such thought. ${ }^{55}$ In support of this criticism the court mistakenly cited State v. Sax:on, ${ }^{57}$ a case which is actually an authority supporting the defendant's theory. The point, however, need not be considered further for it is at most a mere matter of proper wording of the instruction.

A second criticism was that the instruction "proceeds upon the unjustified theory that there is a distinction between the amount of mental ability necessary in premeditation and deliberation, and malice." The Idaho court denied that such a "refinement" is possible and denied that any case holds that a mind capable of entertaining malice aforethought is incapable of premeditation and deliberation. But although the court distinguished certain cases, it ignored others which apply the very "refinement" considered impossible. ${ }^{.3}$ Among these cases is a Con-

55. State v. Van Vlack, 57 Idaho 316, 362, 65 P.2d 736, 757 (1937).

56. It comes as a surprise also to one of the present writers. The instruction requested, as the court said, was taken almost verbatim from WEIHoFE:, Ir:SA:ITY AS A DEFENSE IN CRMrnNal LAw 101 (1933). The wording there used was certainly not intended to lend any support to the notion that a person might be guilty of murder in the second degree even though he had no malice aforethought.

57. 87 Conn. 5, 86 Atl. 590 (1913).

58. E.g., Anderson v. State, 43 Conn. 514 (1876) (defendant convicted of first degree murder granted new trial because of doubt whether he was a proper subject of capital punishment: "The.burden was on the state to show not only that the prisoner was capable of committing a crime, but that he was in a condition to plan and execute 3 cool, deliberate murder. The degree of malice essential to murder in the first degree, like the act of killing, or any other material fact, must be proved beyond a reasonable doubt, or the jur; ought not to convict of the greater offense. Upon that point the jury might have entertained a reasonable doubt, and at the same time may have been satisfied that the act was a crime and that it was their duty to convict of murder in the second degree." Id. at 517-8) ; State v. Anselmo, $46 \mathrm{Utah} 137,148 \mathrm{Pac} .1071$ (1915) (first degree murder conviction reversed where evidence showed that defendant was an epileptic, who had been drinking heavily and who was always badly affected by liquor; jury should have been instructed to consider this evidence in determining appellant's mental capscity to deliberate and premeditate. "While one's mental condition may not excuse the act, it may nevertheless affect the degree of guilt." Id. at 145); State v. Fenil, 45 R.I. 309, 121 Atl. 218 (1923) (evidence that defendant, though not insane, was not in his normal mental state held "relevant on the question of the fixity and duration of the conscious intent or premeditation"). 
necticut decision, ${ }^{59}$ citation to which is found in the Idaho court's own opinion.

A third reason put forth in State v. Van Vlack for rejecting the requested instruction was that there was no demarcation made in the testimony between ability to entertain malice aforethought or deliberation and premeditation. The medical evidence presented on behalf of the defense was that defendant did not know right from wrong, and suffered from a delusion and a manic depressive form of insanity. There was no evidence and no standard by which the jury could determine whether defendant had that greater degree of mentality required to deliberate and premeditate.

This was a point of evidence. The requested instruction was not supported by the evidence as summarized by the court. This ground was enough to support the decision, and the remainder of what the court said may tenably be deemed unnecessary, to the decision and therefore dicta.

Thus the only one of the Idaho court's three criticisms which has general validity is the denial that it is possible to make a distinction between the amount of mental ability necessary for premeditation and deliberation and that necessary for malice aforethought. It must be admitted that court decisions in most states have defined the concepts of "deliberation" and "premeditation" so narrowly that it is almost impossible to understand (much less to get a jury to understand) just what the distinction is between first-degree and second-degree murder..$^{60}$ But if the courts have tended to confuse what the legislatures have tried to keep distinct, they should not use confusion they have created as an argument against the statutory distinction.

In a minority of jurisdictions, moreover, the courts have kept the line drawn by the legislatures fairly clear, by defining premeditation to consist of entertaining in the mind a design to kill, formed prior to the killing; and deliberation to mean "a thinking over with calm and reflective mind" of the considerations for and against the killing. ${ }^{61}$ These definitions seem to agree with what the legislatures obviously

59. Anderson v. State, 43 Conn. 514 (1876).

60 . In the great majority of states, it is held that neither calmness nor any appreciable interval of time is necessary for deliberation or premeditation. The cases are reviewed in Michael and Wechsler, $A$ Rationale of the Law of Homicide, 37 Con. L. REv. 701, 707-8 (1937) and in Knutson, Murder by the Clock, 24 WASH. U. L. Q. 305 (1939). "The elimination of these elements leavés, as Judge Cardozo pointed out, nothing precise as the crucial state of mind but intention to kill." Michael and Wechsler, stopra at 708.

61. Torres v. State, 39 N.M. 191, 43 P.2d 929 (1935); Ex parte Simpson, 37 N.M. 453, 24 P.2d 291 (1933); State v. Kotovsky 74 Mo. 247 (1881) (in deliberation, "Inclination to do the act is considered, weighed, pondered upon"); State v. Speyer, 207 Mo. 540, 106 S.W. 505 (1907) (deliberation "is intended to characterize what are ordinarily termed cold-blooded murders") ; but see State v. Young, 314 Mo. 612, 286 S.W. 29 (1926); Win- 
had in mind-a definition which restricts first degree murder to what a layman would call a "cold-blooded" killing.

The concepts of premeditation and deliberation, like others known to the law, stem from the days of "faculty psychology," when mental processes were neatly tagged as belonging either to the "will," the "reason" or the "emotions." With the recent advances in our understanding of mental processes, it has become increasingly clear that the ideal "rational man" is considerably rarer than we had thought and that the emotions and needs-fear, anger, the desire for power or gainare far more potent as driving forces than had formerly been recognized. The mind, as the generic term used to denote the totality of the manner in which the human organism adapts itself to situations, cannot be considered apart from the body, and therefore not only the heredity, the early environment, the education and native intelligence, but also the physical state, the functioning of the ductless glands, the presence of infection or intoxication are factors in determining the reaction of the individual to any given circumstance. Any of these factors may play a part in modifying the degree to which planning or intellection (premeditation or deliberation) can be applied to a situation and in many conditions short of "insanity" these elements may be psychologically important.

The degree to which socially-approved conduct or response to situations is found depends in considerable measure on the temperament of the actor, the development of his inhibitions, his ability to look ahead to consequences as opposed to "hair-trigger" action, and therefore on his set of conduct, his intelligence, and the soundness of his central nervous system.

To the scientist no less than to the man in the street, the distinction between the mental state which is deemed so reprehensible as to make killing properly a capital offense, and the mental state which is deemed to call for a lesser punishment, is no mere "refinement" but a very real and significant distinction.

It may well be difficult in some cases to say with certainty that the accused, although not so seriously disordered as to come within the right-and-wrong or the irresistible impulse test, nevertheless was incapable, under the circumstances of the case, of premeditating or deliberating the killing. But mere difficulty of application is a dubious

ton v. State, 151 Tenn. 177, 268 S.W. 633 (1925) (act must be done "coolly and in the absence of passion").

In the District of Columbia, "some appreciable time must elapse" to have delibarate and premeditated malice. Bullock v. United States, 122 F.2d 213 (App. D.C. 1941).

The Oregon Code specifically provides that deliberation and premeditation shall be evidenced "by poisoning, lying in wait, or some other proof that the design was formed and matured in cool blood, and not hastily upon the occasion." Ore Cons A:z:. $\$ \$ 23-414$ (1940). 
ground for denying an otherwise allowable defense to crime. Mental abnormality is a condition which can be diagnosed only by experts, functioning under scientifically valid procedures. There is much room for improvement in the procedures employed by the law in determining the facts in insanity cases whether the rule under discussion be adopted or not. It should not be assumed that it is less difficult to determine knowledge of right and wrong or the existence of an irresistible impulse. ${ }^{a 2}$ As Justice Murphy said in the Fisher case:
". . . juries constantly must judge the baffling psychological factors of deliberation and premeditation, Congress having en- trusted the ascertainment of those factors to the good sense of juries. It seems senseless to shut the door on the assistance which medicine and psychiatry can give in regard to these matters, how- ever inexact and incomplete that assistance may presently be. Pre- cluding the consideration of mental deficiency only makes the jury's decision on deliberation and premeditation less intelligent and trustworthy." ${ }^{63}$

Moreover, the assistance which medicine and psychiatry can give may in some cases be reasonably complete and convincing. In the Fisher case itself, the evidence adduced by the defense, according to the transcript of record filed with the petition for certiorari in the Supreme Court of the United States, was to the effect that Fisher had left school at the age of 14 , having then reached the third grade; that his mental age by intelligence tests was eleven years four months; that he had been treated for syphilis; that he had neurological and serological evidence (as shown by changes in certain reflexes and in tests of the spinal fluid) of syphilis of the brain; that he had been a heavy drinker for fourteen years, and that on the night before the murder he had been drinking heavily. A psychiatrist who had made several examinations of Fisher testified that he was an impulsive and aggressive psychopath. In other words, the defendant, already of inferior intelligence and of an impulsive makeup, had suffered damage to his inhibiting, controlling and thinking mechanism, his brain, by reason of both alcohol and syphilis. In the light of these facts, every student of human behavior would agree with Justice Frankfurter's lucid summarization: "His whole behavior seems that of a man of primitive emotions reacting to the sudden stimulus of insult and proceeding from that point without purpose or design." 64

It should be recorded that the prosecution's rebuttal consisted in presenting a psychiatrist who had not examined the defendant and who testified that on the basis of what he had heard of the testimony the

62. See State v. Green, 78 Utah 580, 600, 6 P.2d 177, 185 (1931).

63. 328 U.S. $463,493$.

64. Id. at 481 . 
defendant was "of sound mind," but that "he was very mad and there was provocation." His evidence is summed up in the Supreme Court's majority opinion: "The prosecution had competent evidence that petitioner was capable of understanding the nature and quality of his acts." 65 But if the question of the effect of the defendant's mental con- dition on his ability to deliberate and premeditate had been adequately presented, the majority admitted that "the jury might not have reached the result it did. . . " ${ }^{65}$ Quite likely not. Even a lay jury would probably doubt the ability of a pathological specimen, such as Fisher was shown by uncontroverted medical evidence to be, in the stress of an emotional situation to act "coolly and in the absence of passion," or to "weigh and ponder upon" his actions.

The paucity of reasons advanced by the courts rejecting the rule that mental disorder may serve to reduce the degree of a crime does not mean that the rule is relatively unassailable. Some possible objections exist which have not been mentioned in judicial opinions.

It may be urged that if mental disorder, not justifying an acquittal on the ground of insanity, may be used to reduce an offense to a lower degree or to a lesser crime, juries may misuse this doctrine. They may reach compromise verdicts in cases where they are not certain of a defendant's sanity, or where they cannot agree on a clear-cut verdict of guilt or innocence. Since juries already have wide powrers to convict in a lower degree or for a lesser crime than that charged, and in some states even to fix the punishment, or to determine both the law and the facts, the possibility of compromise verdicts is already so great that opening an additional door will make little difference. The possibility that the jury may misuse this rule in a case where it is not properly applicable is not a good reason for refusing to permit them to apply it in cases where it is legally and logically proper. Such refusal, in a case where the accused is mentally defective, though not to such a serious degree as to require a full acquittal, requires the jury to punish the accused either more severely than the circumstances justify, or not at all. The jury in such circumstances, if they feel that his mental abnormality played a part in his conduct, will often bring in verdicts of not guilty by reason of insanity, even though they are not convinced that the accepted tests have been met. Such verdicts are wrong, but when courts give juries only the alternatives of black and white, who is to blame for wrong results in judging the grays?

Another possible objection is that the rule, if sound at all, is not limited in application to reducing first degree murder to second degree,

65. Id. at 467.

66. Id. at 470 . 
but logically extends to all crimes requiring a specific or even general criminal intent, and that adoption of the rule would thus involve a radical revision of the law governing insanity as a defense to crime.

There seem to be few cases in which mental disorder has been advanced as negativing the intent requisite to any particular crime except first degree murder. ${ }^{67}$ But the rationale of the rule extends to all crimes involving either specific or general intent, including negligent crimes, ${ }^{68}$ and excluding only those statutory crimes in which no wrongful state of mind is required. Although the rule is usually stated as being applicable only to crimes requiring specific intent, a few cases have held that drunkenness may also be shown to negative malice aforethought, and so to reduce a killing to manslaughter. ${ }^{60}$

But if the rule is extended to other cases than murder in the first degree, it would in effect set up a new test of insanity, supplementing the accepted right-and-wrong and irresistible impulse tests. The new test would be: was the defendant, at the time of the act charged, suffering from mental unsoundness which prevented him from entertaining the mens rea, or criminal intent, which is requisite to constitute the crime?

Such a test was proposed some years ago as a substitute for the existing tests by a committee of the American Institute of Criminal Law and Crimlinology composed of some of the country's most eminent authorities in criminal law and psychiatry. Professor Edwin R. Keedy, chairman of the committee, ably urged the merits of such a test. As he pointed out, this test was in accordance with fundamental principles requiring both an act and intent to constitute crime..$^{70}$

While such a test would have a sounder foundation than those now existing, it is doubtful whether it would lead to radically different re-

67. State v. Green, 78 Utah 580, 6 P.2d 177 (1931) held that insanity may have the effect of reducing homicide to voluntary manslaughter.

68. In negligent crimes, the actor has not actual criminal intent, but only has a careless or reckless state of mind dangerous to the life and safety of others. But in these cases, insanity should also be a defense where it has the effect of eliminating "knowledge" or "wilfulness" or other mental element required to constitute the crime. There is some confusion in the law today with reference to the amount of knowledge an actor must possess to be guilty of a negligent crime. Cf. Radin, Intent, Criminal in 8 ENcYc. Soc. Scr. 126 (1932); J. W. C. Turner, The Mental Element in Crimes at Common Lazu, 6 Carsp. L. J. 31 (1936), reprinted in The Modern Approach to Criminal Law 195 (1945).

69. Vance v. Comm., 254 Ky. 667, 72 S.W.2d 43 (1934); State v. Sprouse, 63 Idaho 166,118 P.2d 378 (1941). The modern English cases hold that if the accused was too intoxicated to be aware of the danger, the killing is manslaughter, not murder. Rex $\mathrm{v}$. Meade, [1909] 1 K.B. 895; Director of Public Prosecutions v. Beard, [1920] A.C. 479.

70. The committee proposed a "Criminal Responsibility Bill," the first section of which read:

"Sec. 1. When Mental Disease a Defense. No person shall hereafter be convicted of any criminal charge when at the time of the act or omission alleged against him he was suffering from mental disease and by reason of such mental 
sults. The most common formulation of the right-and-wrong test is that a person is not punishable if at the time of the act he did not lnow the nature and quality of the act he was committing or, knoving it, did not know that it was wrong. One who lacked comprehension of the nature and quality of his act cannot be said to have had any intent with regard to that act, and to this extent the two tests are identical. Also, the irresistible impulse test is comprehended in the "intent" test, for one acting under an irresistible impulse is not acting by free will or intent, but by some abnormal compulsion independent of his will or intention.

There are, however, some situations where the two tests are not identical. For example: defendant kills a man, intending to kill him, under an insane delusion that the deceased is an agent of the devil whom he, defendant, has been divinely commanded to kill. Under the intent rule, defendant is presumably guilty, for he had the requisite intent. But under the right-and-wrong test as applied by courts interpreting "right-and-wrong" to mean moral as distinguished from legal right and wrong, this would be a defense. ${ }^{71}$ The right-and-wrong test would in this situation be the more liberal and humanitarian, and as there is probably universal agreement that any new test should not serve to restrict the defense of insanity, application of the intent rule would be unfortunate. On the other hand, while the intent test will generally be the more liberal, the suggestion that it will open up a new test of insanity is not alarming, for the rule could have little effect beyond the first degree murder situation to which it has thus far been largely limited. Specifically, the only situations in which the "intent" test would be more liberal than the existing tests would, in addition to murder, be those where a person is charged with one act "with intent to" effect some additional purpose not inherent in the act itself, as assault with intent to kill or rape, or burglary, which is a breaking and entering with intent to commit a felony (or a misdemeanor under some statutes). In crimes of that type, there is perhaps room to argue that although defendant knew the nature and quality of the act (the assault, the breaking and entering) and knew that it was wrong (and so was not irresponsible under the right and wrong test), he lacked

disease he did not have the particular state of mind that must accompany such act or omission in order to constitute the crime charged."

See Keedy, Insanity and Criminal Responsibility, $30 \mathrm{HARv}$ L. Rev. 535 (1917); Keedy, Criminal Responsibility of the Insane-A Reply to Professor Ballantine, $12 \mathrm{~J}$. Crns. I. \& Crnumology 14 (1921); also Keedy, Tests of Criminal Responsibility of the Insane, 1 J. Cris. L. \& Crintrology 394 (1910).

71. Wrong was held to mean moral wrong in People v. Schmidt, 216 N.Y. 324, 110 N.E. 945 (1915). In most jurisdictions, the courts have not clearly distinguished between moral and legal wrong in formulating the test. See Wernofen, Irsasirti AS A Deferse in Crminal Law 41-2 (1933). 
mental capacity to form the intent to kill, or to plan the felony. Even here, a liberal interpretation of the right-and-wrong test would permit holding that one who committed an assault likely to prove fatal but who did not actually intend to kill, because too mentally deficient to form such intent, did not know the nature and quality of the act he was committing-i.e., did not know he was committing an assault with intent to kill. ${ }^{22}$

If the doctrine is extended to cases other than murder in the first degree, it may be suggested that the doctrine would result in mentally disordered criminals receiving shorter prison terms and being turned loose on society sooner than the sane and perhaps less dangerous criminals. This objection was in fact raised in a lower Pennsylvania court decision, where the court said: ${ }^{73}$

"It is apparent that one who is a mental defective, who has criminal tendencies, and who has committed what would be unquestionably first degree murder were he normal, is a lasting social menace. His condition is unlike that produced by intoxication, which is only temporary. All such should be permanently confined either in prison or in a hospital unless other legislative provision shall be made for their permanent confinement. It would seem that the protection of human society should be the controlling idea in dealing with them. Acceptance here of the doctrine of reduced responsibility, as in intoxication cases, urged by the defense, means that after a period of years any such defendant surviving at the expiration of sentence for second degree murder will be turned loose on society. It may be logical, as aforesaid, to do so, but not practical, nor would it be an act of kindness to him."

But if an acquittal by reason of insanity must be specifically stated by the jury to be for that reason, ${ }^{74}$ why should not a reduction in the degree of the crime for reason of mental disorder similarly be specified? Whether a defendant is wholly acquitted of arson, for instance, because the jury believed that on account of mental defect or disorder, he did not have the intent to burn a building, or is found guilty of murder in the second degree because mental disorder made him incapable of deliberation and premeditation - in either case, the jury should explain that their verdict was based on such a finding of mental condition. The judge should have power to order the defendant confined for the period proper as punishment for the offense of which he has been found guilty, if any, and in addition, retained for medical care until safe to be at

72. See People v. Schmidt, 216 N.Y. 324, 110 N.E. 945 (1915).

73. Commonwealth v. Scott, 14 Pa. D. \& C. 191, 198 (1930).

74. In at least 39 states and the District of Columbia, where the jury acquits on the ground of insanity, that fact is required to appear in the verdict. WETHOFEN, op. cit, supra note 71 , at 262 . 
large. This procedure could probably be adopted in most states without any additional statutory authority ${ }^{75}$ and would be preferable to those now employed.

\section{VI}

The theory that mental disorder, though not so pronounced as to come within the tests of criminal insanity, may nevertheless negative the particular intent requisite to the crime charged, will continue to make progress in the courts. This is so because it rests upon basic principles "long established and deep rooted." Its logic has not yet been refuted by any court, and it will not permanently be disposed of by mere summary rejection.

75. It is true that the requirement of a special verdict of "not guilty by reason of insanity" is statutory; at common law, a person found to have been mentally irresponsible at the time of the act was entitled to an unconditional acquittal. The great majority of states now require that where the jury acquits on the ground of insanity, that fact should appear in the verdict. But even where no such express provisions exist, the practice is almost universal to instruct to the same effect. On such an acquittal, the statutes usually require or authorize the trial judge to order the defendant committed until be recovers his sanity. WerHofen, op. cit. supra note 71 , at 266-78. In four states and in the federal courts there is no legislation to meet the situation. But it seems that at common law the judge had power to order such a defendant kept in confinement, although the only place where he had power to order him confined was the jail. Id. at 275 n.105. In Georgia, the practice is to regard such a verdict as the equivalent of a finding of a lunacy commission,

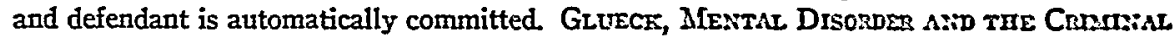
LAw 398 (1925). In Texas, a person acquitted by reason of insanity may have a complaint filed against him asking his commitment. WeIHOFEN, op. cit. supra at 276. Courts would probably have no hesitation in devising a similar arrangement in cases where a person is acquitted of the higher degree of crime because of mental unsoundness, but convieted in a lower degree. The court could in the sentence order him confined, and upon release from penal servitude, turned over to the hospital authorities, on the theory that the jury's verdict not only determined his guilt but also his committability. 